\title{
Seroprevalence of Hepatitis B, Hepatitis C and Human Immunodeficiency Virus in Patients with Thalassemia Major in Zahedan, Southeast of Iran
}

\author{
Hosnie Hoseini ${ }^{1}$ \\ 1. Department of Laboratory Sciences, Zahedan Branch, Islamic Azad University, Zahedan, Iran
}

\begin{abstract}
Background and objectives: Patients with thalassemia are at high risk of hepatitis B, hepatitis C, HIV infections because of the frequent and long-term need for blood transfusion. In the present study, we aimed to determine prevalence of hepatitis B virus (HBV), hepatitis C virus (HCV) and HIV in patients with thalassemia major in a hospital in Zahedan, Iran.

Methods: This descriptive study was performed on 289 thalassemia major patients (130 men and 159 women) who were referred to the Ali ibn Abi Talib hospital in Zahedan, Southeast of Iran. First, serum of patients was checked for presence of antibodies against HB surface antigen, HCV and HIV by ELISA, and then results were confirmed by immunoblotting. Data were analyzed with SPSS 21 software using chi-square test.

Results: Of the 289 patients, 11(3.8\%) were anti-HBs positive, 11(3.8\%) were anti-HCV positive, and none were positive for HIV antibodies. There was no significant difference in the prevalence of the viruses between different age groups. We found no significant correlation between history of HBV vaccination and the absence of infection with the virus in thalassemia patients.

Conclusion: Although the prevalence of HCV and HBV infection is not alarmingly high in thalassemia patients in Zahedan (Southeast of Iran), screening of blood donors using more sensitive detection techniques can effectively reduce the prevalence and incidence of these viral infections in this area.
\end{abstract}

KEYWORDS: Thalassemia major, Hepatitis B, Hepatitis C, AIDS

\section{Received: 2019/02/27 $\quad$ Revised: 2019/04/06 Published:2019/05/23}

*Correspondence: Hosnie Hoseini, Department Oof Laboratory Sciences, Zahedan Branch, Islamic Azad University, Zahedan, Iran

Email: hosniehoseini@gmail.com 


\section{INTRODUCTION}

Transfusion-transmitted viral infections are a major health problem worldwide, especially in developing countries. Transfusion of blood or its components are often applied as a longterm treatment for patients with thalassemia, hemophilia and chronic renal failure [1-3]. Given the increasing use of hepatitis B virus (HBV) vaccine and screening of all donated blood for hepatitis B surface antigen (HBsAg), luckily, the blood transfusionassociated HBV infection rates have dropped dramatically. However, given the lack of vaccines, hepatitis $\mathrm{C}$ virus (HCV) and the human immunodeficiency virus (HIV) infections following blood transfusion are still a major challenge in patients with thalassemia [4]. Since 1995 and after serologic and molecular detection of $\mathrm{HCV}$ and screening of blood donations for the $\mathrm{HCV}$ antigen, the relative incidence of hepatitis $C$ in thalassemia patients has decreased in many countries. However, many thalassemia patients still suffer from AIDS [5-7]. Today, due to the long-term complications of these viral infections, particularly cirrhosis and hepatocellular carcinoma, preventing contamination of blood products with bloodborne viruses is of great importance. Thalassemia is a common disease in Iran, and according to current statistics, the Sistan and Baluchistan Province is a high-prevalence area for the disease. In the present study, we determine the prevalence of HBV, HCV and HIV in patients with thalassemia major in a hospital in Zahedan, Iran.

\section{MATERIALS AND METHODS}

This descriptive study was performed on 289 major thalassemia patients (130 men and 159 women) who were referred to the Ali ibn Abi Talib hospital in Zahedan (Sistan and Baluchestan Province, Iran), between March and August 2017. After obtaining consent from all participants, demographic characteristics including age, ethnicity and vaccination history were collected using a questionnaire. Then, the results of serologic testing (using ELISA) for markers of HBV, $\mathrm{HCV}$ and HIV were extracted from patients' medical record. Positive cases for $\mathrm{HCV}$ and HIV were screened by immunoblotting assay (Pishtazteb Diagnostic, Iran). Data were analyzed with IBM SPSS Statistics 21 using the chi-square test. All statistical analyses were performed at significance level of 0.05 .

\section{RESULTS}

Of 289 patients with thalassemia major, 11 (3.8\%) were HBsAg positive, 11 (3.8\%) were positive for $\mathrm{HCV}$ antibodies, but none were HIV-positive (Table 1).

Table 1. Results of serologic testing in patients with thalassemia major

\begin{tabular}{|c|c|c|c|c|c|c|}
\hline \multirow{3}{*}{ Subjects } & \multicolumn{6}{|c|}{ Results } \\
\hline & \multicolumn{2}{|c|}{ Number of positives (\%) } & \multicolumn{2}{|c|}{ Number of negatives (\%) } & \multirow{2}{*}{ Total } & \multirow{2}{*}{ P-value } \\
\hline & Male & Female & Male & Female & & \\
\hline HBsAg & $3(1.03)$ & $8(2.76)$ & $127(43.94)$ & $151(52.24)$ & $289(100)$ & \multirow{3}{*}{$\mathrm{P}>0.05$} \\
\hline Anti-HCV & $7(2.42)$ & $4(1.38)$ & $123(42.56)$ & $155(53.63)$ & $289(100)$ & \\
\hline Anti-HIV & $0(0)$ & $0(0)$ & $130(44.98)$ & $159(55.01)$ & $289(100)$ & \\
\hline
\end{tabular}

The results of serologic tests had no significant correlation with sex, age and history of vaccination. The prevalence of
HBV and HCV was highest (34.9\%) in patients above the age of 51 years (Table 2). 
Journal of Clinical and Basic Research (JCBR): 2019: Vol 3: N.1.P: 29-33

Table 2. Results of serologic testing in patients with thalassemia major based on age

\begin{tabular}{|c|c|c|c|c|c|c|c|c|c|}
\hline \multirow{2}{*}{ Variable } & \multicolumn{8}{|c|}{ Age group (years) } & \multirow{2}{*}{ P-value } \\
\hline & & $\leq 10$ & $11-20$ & $21-30$ & $31-40$ & $41-50$ & $\geq 51$ & Total & \\
\hline \multirow{2}{*}{ HBsAg } & Positive & 0 & 3 & 1 & 0 & 1 & 6 & \multirow{2}{*}{$289(100)$} & \multirow{6}{*}{$\mathrm{P}>0.05$} \\
\hline & Negative & 24 & 14 & 65 & 43 & 37 & 95 & & \\
\hline \multirow{2}{*}{ Anti-HCV } & Positive & 1 & 0 & 3 & 0 & 2 & 5 & \multirow{2}{*}{$289(100)$} & \\
\hline & Negative & 23 & 17 & 63 & 43 & 36 & 96 & & \\
\hline \multirow{2}{*}{ Anti-HIV } & Positive & 0 & 0 & 0 & 0 & 0 & 0 & \multirow{2}{*}{$289(100)$} & \\
\hline & Negative & 24 & 17 & 66 & 43 & 38 & 101 & & \\
\hline
\end{tabular}

\section{DISCUSSION}

HBV is one of the most common human pathogens in the world, which is associated with significant morbidity and mortality (8). Patients with thalassemia major are at high risk of HBV infection (9). In our study, the HBsAg was detected in $3.8 \%$ of the patients with thalassemia major, which is somewhat higher than the rates reported in other studies. For example, in a study by Karimi and Ghavanini in Shiraz (Iran) on 755 patients with thalassemia, $0.53 \%$ of the patients were positive for the HBsAg (10). Moreover, in a study in Qazvin (Iran), the prevalence of HBsAg-positive thalassemia patients was $1.1 \%$ (11). In a study by Jamal et al. in Malaysia on 85 thalassemia patients, $2.3 \%$ of the patients were positive for the HBsAg (12). In Bangladesh, Khan et al. reported that $13.6 \%$ of children with thalassemia are positive for the HBsAg (13). According to a study in Italy, continuation of the hepatitis B vaccination program can reduce the risk of developing HBV infection through blood transfusion (14).

$\mathrm{HCV}$ is a major cause of viral hepatitis worldwide, and an estimated 2-3\% of the world's population is living with $\mathrm{HCV}$ infection $(15,16)$. However, prevalence rates may vary due to various factors including the type of selective testing for $\mathrm{HCV}$, sensitivity of the test for the detection of HCV antibodies and performing annual blood screening. In a study in India, the incidence of HCV was
$25.5 \%$ in thalassemia patients and $1.78 \%$ in healthy controls (16). In a recent study in Columbia, the seroprevalence of $\mathrm{HCV}$ was $32.2 \%$ in hemophilia patients, $1.6 \%$ in hemodialysis patients, $7.1 \%$ in patients (17).

In Bangladesh, the prevalence of $\mathrm{HCV}$ was $12.5 \%$ in children with thalassemia and $0.9 \%$ in healthy individuals (18). According to other studies in Iran, the prevalence of HCV in patients with thalassemia was $15.7 \%$ in Shiraz (10) and 24.2\% in Qazvin (11).

\section{CONCLUSION}

Although the prevalence of $\mathrm{HCV}$ and $\mathrm{HBV}$ is not alarmingly high in thalassemia patients in Zahedan (Southeast of Iran), screening of blood donors using more sensitive detection techniques can effectively reduce the prevalence and incidence of these viral infections in this area.

\section{ACKNOWLEDGMENTS}

The authors wish to thank the personnel of Ali ibn Abi Talib Hospital in Zahedan for their cooperation in this study.

\section{DECLARATIONS \\ Funding}

This study received financial support from the Islamic Azad University of Zahedan (Grant no: 14-11-5-784). 


\section{Ethics approvals and consent to participate}

The study protocol was approved by the ethics committee of Islamic Azad University of Zahedan (ethical approval code: AE-MLSWI-064-02).

\section{Conflict of interest}

The authors declare that there is no conflict of interest regarding publication of this article.

\section{REFERENCES}

1. Galanello R, Origa R. Beta-thalassemia: Orphanet J Rare Dis. Journal of Continuing Education Topics \& Issues. 2012;14(1):33-4.

2. Din G, Malik S, Ali I, Ahmed S, Dasti JI. Prevalence of hepatitis $\mathrm{C}$ virus infection among thalassemia patients: a perspective from a multiethnic population of Pakistan. Asian Pacific journal of tropical medicine. 2014;7: 127-S33. [DOI:10.1016/S1995-7645(14)60218-2]

3. Javadzadeh SH, Attar M, Yavari M, Savabieh S. Study of the prevalence of Hepatitis B, C and HIV infection in Hemophilia and Thalassemia population of Yazd. 2006:31(2).90-95.

4. Mirmomen S, Alavian S-M, Hajarizadeh B, Kafaee J, Yektaparast B, Zahedi M-J, et al. Epidemiology of hepatitis B, hepatitis C, and human immunodeficiency virus infecions in patients with beta-thalassemia in Iran: a multicenter study. Arch Iran Med. 2006;9(4):31923.

5. Ataei B, Hashemipour M, Kassaian N, Hassannejad R, Nokhodian Z, Adibi P. Prevalence of anti HCV infection in patients with Betathalassemia in isfahan-iran. International journal of preventive medicine. 2012;3.118.

6. Ott J, Stevens G, Groeger J, Wiersma S. Global epidemiology of hepatitis B virus infection: new estimates of age-specific HBsAg seroprevalence and endemicity. Vaccine. 2012;30(12):2212-9. [DOI:10.1016/j.vaccine.2011.12.116]

7. Rezvan H, Abolghassemi H, Kafiabad SA. Transfusion-transmitted infections among multitransfused patients in Iran: a review. Transfusion Medicine. 2007;17(6):425-33. [DOI:10.1111/j.1365-3148.2007.00794.x]
8. Jang T-Y, Lin P-C, Huang C-I, Liao Y-M, Yeh $\mathrm{M}-\mathrm{L}$, Zeng Y-S, et al. Seroprevalence and clinical characteristics of viral hepatitis in transfusiondependent thalassemia and hemophilia patients. PLoS One. 2017;12(6):83-87. [DOI:10.1371/journal.pone.0178883]

9. Al-Mahroos FT, Ebrahim A. Prevalence of hepatitis $\mathrm{B}$, hepatitis $\mathrm{C}$ and human immune deficiency virus markers among patients with hereditary haemolytic anaemias. Annals of tropical paediatrics. 1995;15(2):121-8. [DOI:10.1080/02724936.1995.11747759]

10. Karimi M, Ghavanini A. Seroprevalence of hepatitis B, hepatitis $\mathrm{C}$ and human immunodeficiency virus antibodies among multitransfused thalassaemic children in Shiraz, Iran. Journal of paediatrics and child health. 2001;37(6):564-6. [DOI:10.1046/j.14401754.2001.00709.x]

11. Alavian S, Tabatabaei S, Lankarani K. Epidemiology of $\mathrm{HCV}$ infection among thalassemia patients in eastern Mediterranean countries: a quantitative review of literature. Iranian Red Crescent Medical Journal. 2010;12(4):365.

12. Jamal R, Fadzillah G, Zulkifli SZ. Seroprevalence of hepatitis B, hepatitis C, CMV and HIV in multiply transfused thalassemia patients: results from a thalassemia day care center in Malaysia. The Southeast Asian. 1998:13(3):14-20

13. Khan WA, Banu B, Amin SK, Selimuzzaman $\mathrm{M}$. Prevalence of beta thalassemia trait and $\mathrm{Hb} \mathrm{E}$ trait in Bangladeshi school children and health burden of thalassemia in our population. DS (Child) H J. 2005; 21 (1) : 1-7

14. Elisabetta F, Barbara B, Maria Giulia M. Hepatitis B: Epidemiology and prevention in developing countries. World J Hepatol. 2012 .27; 4(3): 74-80. [DOI:10.4254/wjh.v4.i3.74]

15. Mohamoud YA, Riome S, Abu-Raddad LJ. Epidemiology of hepatitis $\mathrm{C}$ virus in the Arabian Gulf countries: Systematic review and metaanalysis of prevalence. International Journal of Infectious Diseases. 2016;46:116-25. [DOI:10.1016/j.ijid.2016.03.012] 
16. Averhoff M, Glass N, Holtzman D. Global Burden of Hepatitis C: Considerations for Healthcare Providers in the United States. Clinical Infectious Diseases. 2012: 55(1):10-15 [DOI:10.1093/cid/cis361]

17. Shah N, Mishra A, Chauhan D, Vora C, Shah N. Study on effectiveness of transfusion program in thalassemia major patients receiving multiple blood transfusions at a transfusion centre in Western India. Asian journal of transfusion science. 2010;4(2):94-98. [DOI:10.4103/09736247.67029]

18. Hoz F De la, Muñoz MM, Jaramillo S, Estrada C. Hepatitis $\mathrm{C}$ virus seroprevalence in multitransfused patients in Colombia. Journal of Clinical Virology. 2005: 34(2).33-38 [DOI:10.1016/S1386-6532(05)80032-0]

19. Shahjalal H. Thalassemic Children in Bangladesh. Journal Medical Science .2007:7(1).131-135 